\title{
PENGENDALIAN EMOSI MENURUT PSIKOLOGI ISLAM
}

\author{
R. Rachmy Diana \\ Program Studi Psikologi UIN Sunan Kalijaga Yogyakarta \\ Email: rachmy.diana@yahoo.com
}

\begin{abstract}
ABSTRAK
Tulisan ini bermaksud mengupas beberapa tema psikologi yang ada dalam Al-Qur'an. Al-Qur'an secara luar biasa mengupas bagaimana orang-orang beriman memiliki formula untuk bisa menghadapi berbagai konflik bathin, mengendalikan dorongan bawah sadar yang mengarah pada keburukan, serta melakukan tindakan-tindakan positif untuk mereduksi ketegangan emosi dalam setiap perjalanan kehidupan yang dialaminya.
\end{abstract}

Kata kunci: dorongan bawah sadar, konflik batin, pengendalian emosi

\section{Pendahuluan}

Setiap individu secara alamiah telah memiliki dorongan dari dalam dirinya sejak keberadaannya. Dorongan-dorongan itu berfungsi menggerakkan manusia untuk memenuhi kebutuhannya. Sepanjang kehidupannya dorongan itu ada dan berperan besar dalam mengantarkan individu menggapai keberhasilan. Namun, dorongan yang tak terkendali memungkinkan terjadinya kerusakan pada diri manusia dan lingkungannya bila tidak ada pengendalian emosi. Tulisan ini akan mendiskusikan keterkaitan antara dorongan tidak sadar, konflik batin, dan pengendalian emosi manusia.

Pendekatan yang digunakan dalam tulisan ini adalah pendekatan psikologi Islam. Psikologi Islam sendiri dapat diartikan suatu studi tentang jiwa dan perilaku manusia yang didasarkan pada pandangan dunia Islam (Nashori, 2010). Psikologi Islam juga dapat diartikan sebagai kajian Islam yang berhubungan dengan aspek-aspek dan perilaku kejiwaan manusia agar secara sadar dapat membentuk kualitas diri yang lebih sempurna dan mendapatkan kebahagiaan hidup dunia dan akhirat (Mujib \& Mudzakir, 2001). Sebagaimana pengertian yang ditunjukkan oleh pengkaji psikologi Islam di atas tulisan ini didasarkan pada pandangan dunia Islam yang bersumber dari al-ur'an dan al-Hadits yang mengkaji sebagian fenomena manisa da;am hal ini adalah dorongan tidak sadar, konflik batin, dan pengendalian emosi manusia

\section{Dorongan Bawah Sadar}

Istilah dorongan bawah sadar atau ketidaksadaran mengacu pada salah satu teori utama dalam psikologi kepribadian, yakni teori psikoanalisis yang dimotori oleh Sigmund Freud. Tokoh psikoanalisis ini berpandangan bahwa kepribadian manusia didominasi oleh ketidaksadaran. Ia bahkan mengatakan bahwa kesadaran hanya merupakan bagian kecil dari struktur kepribadian manusia, sementara yang dominan adalah ketidaksadaran. Kesadaran adalah apa yang terlihat di permukaan, sementara ketidaksadaran adalah apa yang ada di bawah permukaan yang begitu luas (Feist \& Feist, 2008; Hall \& Lindzey, 2000).

Penjelasan tentang dorongan bawah sadar erat kaitannya dengan pembentukan kepribadian manusia. Menurut pandangan Freud, kepribadian manusia ini merupakan hasil proses dinamis yang melibatkan id, superego, dan ego (Feist \& Feist, 2008). Id adalah struktur kepribadian 
manusia yang bersifat biologis. Ia ada sejak adanya manusia. Id didominasi oleh alam bawah sadar yang berisi dorongan, impuls, motif atau needs yang sangat mempengaruhi perilaku. Sementara itu, superego adalah struktur kepribadian manusia yang berisi hati nurani. Ia terbentuk berdasar proses pendidikan dan pengasuhan yang didapatkan individu dari lingkungannya. Ego berperan sebagai jembatan yang mengkompromikan kepentingan id dan superego (Freud, 2001; Freud, 2002).

Bagaimana teori kepribadian Islam memandang ketidaksadaran? Kepribadian dalam literatur Islam dimaknai sebagai integrasi sistem qalbu, akal dan nafs manusia yang mengarahkan tingkah laku (Mujib \& Mudzakir, 2001; Nashori, 2002; Sutoyo, 2007). Qalbu adalah potensi fitrah ilahiyah/ketuhanan yang merupakan aspek supra kesadaran manusia yang memiliki daya emosi (rasa) dan moral. Akal merupakan fitrah insaniyah/kemanusiaan sebagai aspek kesadaran manusia yang memiliki daya kognisi. Sedangkan nafsu (fitrah hayawaniyah) merupakan aspek pra atau bawah kesadaran manusia yang memiliki daya konasi (karsa).

Dari penjelasan di atas, jelaslah bahwa dorongan bawah sadar didominasi oleh nafsu sebagai dorongan terendah, yaitu dorongan hayawaniyah. Prinsip kerjanya hanya mengejar kenikmatan (pleasure) duniawi dan ingin mengumbar nafsu-nafsu impulsifnya. Apabila sistem kendali qalbu dan akal melemah, maka nafsu mudah mengaktualisasikan dorongan hayawaniyah-nya. Tetapi apabila sistem kendali qalbu dan akal tetap berfungsi dengan baik, maka daya nafsu melemah. Nafsu ini memiliki daya tarik sangat kuat dibandingkan kedua sistem fitrah nafsani lainnya (qalbu dan akal), disebabkan oleh adanya tipu daya setan dan tipuan-tipuan impulsif lainnya.

Walaupun sifat alami dari dorongan nafsu selalu mengarah pada amarah yang buruk, namun apabila nafsu tersebut diberi rahmat oleh Allah, maka ia akan menjadi daya positif. Hal ini sebagaimana firman Allah SWT dalam QS 12:53, "Sesungguhnya nafsu itu selalu menyerukan pada perbuatan buruk, kecuali nafsu yang diberi rahmat oleh Tuhannya."

\section{Konflik Batin}

Setiap manusia pasti pernah mengalami konflik batin dalam dirinya yang dalam istilah umum dikenal sebagai dilema. Konflik batin ini melibatkan struktur kepribadian, dalam hal ini qalbu, akal, dan nafsu (Mujib \& Mudzakir, 2001; Nashori, 2002; Sutoyo, 2007). Dalam perspektif Freudian, konflik itu terjadi akibat adanya keterkaitan antara id, superego, dan ego.

Dalam Al-Quran terdapat penggambaran konflik batin ini sebagaimana yang dialami oleh kaum munafik yang tidak memiliki prinsip dan selalu berubah-ubah pandangannya. "Mereka dalam keadaan ragu (antara iman atau kafir), tidak termasuk golongan ini dan tidak pula golongan itu. Barangsiapa dibiarkan sesat oleh Allah, maka kamu tidak akan mendapatkan jalan (untuk memberi) petunjuk baginya" (QS 4 :143). Manusia akan mengalami dilema/konflik batin manakala dihadapkan pada dua atau lebih situasi/ rangsangan (stimuli) yang bertentangan. Beberapa stimuli ini bisa jadi seluruhnya positif atau negatif, atau campuran antara keduanya.

Para ahli membagi konflik batin manusia ke dalam tiga kategori (Hude,2006) yakni: konflik mendekat-mendekat (approach-approach conflict), konflik menjauh-menjauh (avoidance-avoidance conflict), dan konflik menjauh-mendekat (approach-avoidance conflict). Pertama: Konflik mendekat-mendekat (approach-approach conflict). Konlik jenis ini muncul ketika seseorang dihadapkan pada dua tujuan yang sama-sama mengandung nilai positif. Misalnya seseorang yang dihadapkan pada pilihan apakah akan menggunakan waktu senggangnya untuk membaca al-quran atau melaksanakan sholat sunnah. Memilih salah satu di antara keduanya sama saja, tidak akan menjadi beban bagi pemilihnya. Umumnya konflik jenis 
ini mudah diatasi dan mungkin hanya menimbulkan emosi yang relatif lebih rendah dari jenis konflik lainnya.

Kedua: Konflik menjauh-menjauh (avoidance-avoidance conflict). Konflik ini merupakan konflik yang terjadi dengan melibatkan dua hal negatif/tidak nyaman pada saat bersamaan. Contohnya pada tahun 2003, jamaah haji Indonesia didera konflik jenis ini. Berjalan kaki sekitar $7 \mathrm{KM}$ dari muzdalifah ke mina di bawah terik matahari padang pasir atau kehilangan waktu melontar jumrah pertama karena harus menunggu kedatangan bis yang akan membawa mereka ke muzdalifah. Kaidah ushul fiqh membantu kaum muslimin mengatasi konflik jenis ini, yaitu "apabila dua mafsadah (keburukan) bertemu maka harus diperhatikan mana yang lebih besar kerusakannya, kemudian mengambil yang lebih ringan mafsadahnya.“

Ketiga: Konflik menjauh-mendekat (approach-avoidance conflict). Konflik ini merupakan jenis konflik yang lebih sulit dipecahkan. Konflik ini terjadi apabila suatu hal mengandung unsur positif dan negatif sekaligus. Contohnya dalam Al-Qur'an dikisahkan Yusuf yang sedang berhadapan dengan dua pilihan positif dan negatif sekaligus, yakni menetap pada keluarga yang telah memungutnya (seorang pejabat negara) atau tergoda oleh istri pejabat itu (QS 12:22-35).

Setiap konflik tidak selalu bermuatan tunggal, tetapi bisa melibatkan berbagai persoalan yang kompleks sekaligus. Pada beberapa alternatif pilihan yang ada terkandung banyak unsur positif dan negatif secara simultan. Konflik jenis ini lazim disebut multiple approach-avoidance conflict. Sebagai contoh seorang wanita yang dihadapkan pada pilihan berkarier di luar rumah atau menikah dan berkeluarga. Kedua-duannya mengandung sisi-sisi positif dan negatif sekaligus.

Dalam perspektif psikologi Islam, ada tiga kondisi saat terjadi konflik antara kalbu, akal, dan nafsu. Pertama adalah diri yang tenang (al-nafs al-mutmainnah), di mana kalbu mengendalikan akal dan nafsu. Kedua adalah diri yang terombang-ambing (al-nafs allawwamah), yang ditandai oleh dominasi akal atas kalbu dan nafsu. Ketiga adalah diri yang tergadaikan (al-nafs al-ammarah), yaitu ketika nafsu menguasai kalbu dan akal (Nashori, 2008).

Ajaran Islam mengajarkan pada umatnya untuk melakukan langkah spiritual di samping menggunakan kalbu (hati nurani) dan akal pikiran dalam menentukan pilihan yang tepat maupun menghadapi dilema kehidupan. Salah satu yang diajarkan oleh Nabi SAW dalam memilih keputusan terbaik adalah dengan melaksanakan sholat istikharah untuk memohon petunjuk dari Dzat Yang Maha Tahu, Allah SWT.

\section{Pengendalian Emosi}

Pengendalian emosi sangatlah penting dalam kehidupan manusia, khususnya untuk mereduksi ketegangan yang timbul akibat konflik batin yang memuncak. Dalam konteks ini, AlQur'an memberi petunjuk pada manusia agar mengendalikan emosinya guna mengurangi ketegangan-ketegangan fisik dan psikis serta efek negatifnya.Begitupula pula dalam hadits Nabi SAW banyak yang mengingatkan pengikutnya untuk selalu mengontrol emosi agar terciptanya kehidupan yang selaras dan seimbang.

Salah satunya adalah pesan Rasulullah SAW sebagaimana diriwayatkan oleh al Bukhari, Malik dan at Tirmidzi, Abu Hurairah berkata: "ada seseorang yang berkata kepada Nabi, nasehatilah saya!Beliau berkata: 'Janganlah kamu marah.' Orang itu berkata lagi beberapa kali dan Rasul tetap menjawab: 'Janganlah kamu marah'.' 
Dalam hadits lain yang diriwayatkan oleh Ath Thabrani, Rasulullah SAW menjawab janganlah marah ketika ada orang yang bertanya tentang apa yang bisa menyelamatkannya dari murka Allah (Najati, 2001; Najati, 2005). Demikian pula pada kesempatan lain Nabi Muhammad menanyakan pada para sahabat: "Siapakah orang yang gagah di antara kalian?" Mereka menjawab: "Orang yang tidak bisa dibanting oleh oranglain." Beliau berkata, "Bukan itu, orang gagah adalah orang yang mampu menguasai dirinya ketika marah "( HR Muslim dan Abu Dawud)

Secara teori, terdapat tiga model pengendalian emosi yang dilakukan oleh seseorang ketika menghadapi situasi emosi (Hube, 2006), yaitu pengalihan, penyesuaian kognitif, dan strategi koping. Pertama: Pengalihan/Displacement. Pengalihan merupakan suatu cara mengalihkan atau menyalurkan ketegangan emosi pada obyek lain. Di antara cara yang sering digunakan yakni katarsis, rasionaliasi dan dzikrullah. Katarsis ialah suatu istilah yang mengacu pada penyaluran emosi keluar dari keadaannya. Sebutan lain untuk katarsis ini juga dikenal istilah 'ventilasi'. Sebagai contoh, orang yang sedang jatuh cinta namun tak kuasa menyatakan cintanya karena berbagai sebab, akhirnya dia menulis novel atau kumpulan puisi cinta yang tak lain merupakan penyaluran emosi dari apa yang sedang dialaminya.

Bentuk pengalihan berikutnya adalah rasionalisasi. Rasionalisasi merupakan proses pengalihan dari satu tujuan yang tak tercapai kedalam bentuk lain yang diciptakan dalam pikirannya. Yang dirasionalisasikan adalah alasan yang digunakan dalam pengalihan itu. Menurut Atkinson, Atkinson, dan Hilgard (1991), ada dua tujuan dari rasionalisasi ini , yaitu (1) mengurangi kekecewaan ketika tujuan tidak tercapai. (2) memberi motif yang layak atas suatu tindakan dengan memberi alasan yang dapat diterima secara rasio. Sejalan dengan ini Al-Qur'an (QS 4:79, QS 3:91) memberikan banyak pelajaran tentang pentingnya manusia mengambil sisi baik atas setiap kejadian, walaupun pada mulanya itu sesuatu yang dianggap buruk dan tidak mengenakkannya. Cara tersebut dikenal dengan hikmah, yang dapat membuat manusia tidak larut dalam emosi negatif dan berpikir tentang kebaikan apa yang Allah kehendaki dibalik tidak tercapainya suatu tujuan. Sebagai contoh ketika seseorang berupaya menikahi seseorang yang sangat dicintainya, ternyata mengalami kegagalan. Hikmah diperoleh seseorang dengan mencoba mengenali kebaikan apa yang muncul setelah kegagalan itu. Ternyata kegagalan itu dimaksudkan sebagai penundaan akan kenikmatan yang lebih besar, karena pada akhirnya dia mendapatkan orang yang lebih shalih/shalihah, lebih baik masa depannya, lebih baik dari sisi keturunannya, dan seterusnya.

Zikrullah merupakan salah satu cara pengalihan manakala manusia mengalami kesulitan atau permasalahan. Mengingat Allah ini dapat berupa kalimah thayyibah, wirid, doa maupun tilawah Quran. Efek dari aktivitas tersebut, seorang muslim akan merasakan ketentraman dalam menghadapi masalahnya (QS 13:38), dan hal itu baik untuk menghasilkan sikap optimis ketika ada harapan tidak terpenuhi. Selain itu, zikrullah juga dapat mengalihkan emosi negatif yang dialami seseorang menjadi emosi positif dengan sebab kondisi tenang dan damai yang dirasakannya. Riset-riset terbaru menunjukkan bahwa pelatihan relaksasi zikir untuk menurunkan stres penderita hipertensi esensial (Anggraieni, 2014), pelatihan relaksasi zikir efektif meningkatkan kesejahteraan subjektif istri yang mengalami infertilitas (Wahyunita, 2013), terapi relaksasi otot progresif dan zikir efektif menurunkan kecemasan hipertensi esensial pralansia (Luznizanuri 2013), terapi relaksasi zikir efektif menurunkan stres penderita ginjal kronik yang menjalani hemodialisis (Sadif, 2013).

Kedua: Penyesuaian Kognitif / Cognitive Adjustment. Landasan teori penyesuaian kognitif adalah realitas bahwa kognisi seseorang sangat mempengaruhi sikap dan perilakunya. Penyesuaian kognitif merupakan cara yang dapat digunakan untuk menilai sesuai menurut 
paradigma seseorang yang disesuaikan dengan pemahaman yang dikehendaki. Pengalamanpengalaman dalam peta kognisi dicocokkan dengan berbagai hal yang paling mungkin dan pas untuk diyakini. Ada 3 bentuk penyesuaian kognitif, yaitu atribusi kognitif, empati dan altruisme.

Atribusi kognitif adalah suatu mekanisme yang menempatkan persepsi berada dalam kondisi positif. Setiap masalah selalu dilihat dari sisi positifnya. Pada kenyataannya, atribusi positif selalu beriringan dengan atribusi negatif terutama yang mengandung konflik yang berkecamuk dalam kehidupan manusia. Sebagai contoh ketika seorang sufi terluka tangannya karena teriris pisau, maka alih-alih merasa sedih atau marah, namun mereka meyakini itu sebagai tanda kasih sayang Allah yang mengucurkan darah haram yang mungkin ada dalam diri mereka sehingga kelak tak tersentuh api neraka.

Empati merupakan kesadaran dalam diri seseorang untuk turut merasakan apa yang sedang dialami oranglain, baik berupa kesulitan maupun musibah. Dengan kesadaran berempati ini seseorang dapat menimba pengalaman oranglain dalam mereduksi gejolak emosi tatkala peristiwa yang sama menimpa dirinya.

Ajaran Islam mendorong sikap empati ini karena dengan sikap ini akan melahirkan ketulusan dan dorongan untuk menolong oranglain. Banyak kisah dalam Alquran tentang bagaimana Rasulullah berempati pada para Nabi pendahulunya (QS 35:4, QS 6 :34,QS 22:42).

Altruisme merupakan salah satu prinsip dalam relasi interpersonal. Gambaran altruisme dalam Al Quran dapat dibaca misalnya pada QS 76:8-9 yang melukiskan orang yang memberi pertolongan kepada sesama tanpa pamrih, kecuali mengharap ridho Allah.

Ketiga: Coping strategy. Coping dimaknai sebagai tindakan seseorang dalam menanggulangi, menerima atau menguasai suatu kondisi yang tidak diharapkan (masalah). Dalam teori psikologi, terdapat dua strategi coping, yaitu emotional focus copingyang berarti fokus penanggulangan pada emosi yang dirasakan, dan problem focus copingyang secara singkat berarti fokus penanggulangan pada masalah yang dihadapi.Adapun dalam ajaran Islam terdapat 2 mekanisme dalam pengendalian emosi dan menanggulangi masalah, yakni mekanisme sabar dan syukur serta pemaafan. Sabar adalah alan terbaik agar seseorang tidak larut dalam emosi negatif. Secara ilmiah dan alamiah, suatu peristiwa yang menimbulkan emosi utama (mayor) dapat diikuti oleh beberapa emosi minor sekaligus. Sebagaimana yang dikisahkan dalam hadis Rasulullah SAW berikut ini :

"Nabi saw menjumpai seorang wanita sedang menangis di sebuah kuburan (dalam riwayat lain menangisi kematian anaknya) lalu menasehati, "Bertaqwalah kepada Allah dan bersabarlah!" Wanita itu menjawab ketus karena tak mengetahui yang menasehatinya adalah Nabi, " Bukan urusanmu, kamu tak merasakan musibah yang saya alami!”. (beberapa waktu berselang) wanita itu datang ke rumah Nabi saw dan mengatakan: "mohon maaf, saya tidak mengenalimu waktu itu (kini aku sudah bersabar)". Kemudian Nabi bersabda: "sabar itu pada benturan pertama (diawal peristiwa)" (HR Bukhari, Muslim, Turmudzi, Nasaai, Abu Dawud, Ibnu Majah, Ahmad).

Kesedihan mendalam seorang ibu atas meninggalnya anak yang disayangi dalam hadis tersebut adalah emosi mayor. Manakala ada pihak yang mencoba menasehati, justru menimbulkan reaksi emosi kedua (minor 1) yaitu marah. Penyesalan atas kemarahan yang ditunjukkan kepada orang yang bermaksud memberi nasehat adalah emosi minor ke-2, apalagi setelah tahu bahwa pemberi nasehat itu adalah Rasulullah, menimbulkan rasa bersalah bercampur rasa malu sebagai emosi minor ke-3 \& 4. Seluruh emosi yang timbul itu akan menambah beban masalah bagi yang mengalaminya. Karena itu, adalah tepat jika Islam mengajarkan respon terbaik manakala seseorang ditimpa masalah atau kesulitan yaitu dengan bersabar. 
Selain sabar, ajaran Islam melalui lisan Nabi Muhammad mengajarkan tentang pentingnya pengendalian emosi dengan cara banyak bersyukur. Syukur ini sebuah bentuk pengakuan bahwa segala kenikmatan berasal dari Allah dan akan kembali kepada-Nya kapanpun Dia kehendaki. Sikap ini dalam menjaga seorang mukmin dari sikap berlebihan (euforia) dalam menerima kesulitan maupun kemudahan. Sebagaimana Allah berfirman dalam QS 57:23 sebagai berikut :

"Supaya kamu jangan berduka cita terhadap apa yang luput dari kamu, dan supaya kamu jangan terlalu gembira terhadap apa yang diberikan-Nya kepadamu. Dan Allah tidak menyukai setiap orang yang sombong lagi membanggakan diri."

Pemaafan (forgiveness) adalah starategi koping yang penting adlam Islam. Rasulullah SAW adalah pribadi agung yang sangat terkendali emosinya dan mampu menahan amarahnya terhadap stimuli negatif yang dihadapi. Al Quran menggambarkan bahwa sekiranya beliau termasuk orang yang suka mengumbar amarah, niscaya umat telah meninggalkannya (QS 3:159). Menahan marah bukan berarti menyimpannya yang sewaktu-waktu diletupkan. Pemberian maaf adalah sebuah proses meleburkan semuanya dan menghadirkan kelapangan dalam hati.

Salah satu ayat yang menjelaskan tentang keutamaan memberi maaf, di antaranya, "yaitu orang-orang yang menafkahkan (hartanya), baik di waktu lapang maupun sempit dan orangorang yang menahan amarahnya dan memaafkan (kesalahan) oranglain. Allah menyukai orang-orang yang berbuat kebajikan (QS 3:134).

"Dan jika kamu memberikan balasan, maka balaslah dengan balasan yang sama dengan siksaan yang ditimpakan kepadamu. Akan tetapi jika kamu bersabar, sesungguhnya itulah yang lebih baik bagi orang-orang yang sabar.” (QS an-Nahl/16:126-127).

"Dan balasan suatu kejahatan adalah kejahatan yang serupa, maka barang siapa memaafkan dan berbuat baik maka pahalanya atas (tanggungan) Allah. Sesungguhnya Dia tidak menyukai orang-orang yang zalim." (QS asy-Syuura/42:40).

Pemaafan (forgiveness) sendiri terbukti dapat berperan dalam menyelesaikan berbagai konflik yang terjadi antar individu, antar kelompok, bahkan antar bangsa/negara (Fincham, Beach, \& Davilla, 2004; Nashori, 2010), mening-katkan pengendalian diri (Worthington dkk, 2005), meminimalisasi konflik dengan sesama (Luskin, dalam Martin, 2003), bahkan dapat menjadikan orang yang mendzalimi tidak melakukan tindak kedzaliman di masa yang akan datang (Wallace dkk, 2008).

\section{Kesimpulan}

Al-Quran secara luar biasa telah mengupas bagaimana orang-orang beriman memiliki formula untuk bisa menghadapi berbagai konflik bathin, mengendalikan dorongan bawah sadar yang mengarah pada keburukan serta melakukan tindakan-tindakan positif untuk mereduksi ketegangan emosi dalam setiap perjalanan kehidupan yang dialaminya. Kemampuan mengendalikan ketegangan emosi, konflik batin, dan mengendalikan dorongan bawah sadar akan mengantarkan individu kepada kehidupan yang bahagia.

\section{Daftar Pustaka}

Anggraieni, Widura N. 2014. Pelatihan relaksasi zikir untuk menurunkan stres penderita hipertensi esensial. Tesis. Yogyakarta: Program Pascasarjana Fakultas Psikologi dan Ilmu Sosial Budaya UII. 
Atkinson, Rita L. Atkinson, R.B., \& Hilgard. 1991. Pengantar Psikologi. Jakarta: Penerbit Erlangga.

Feist, Jest \& G.J. Feist. 2008. Theories of Personality. Terjemahan. Yogyakarta: Pustaka Pelajar.

Fincham, Frank D., Steven R. Beach, \& Joanne Davilla. 2004. Forgiveness and Conflict Resolution in Marriage. Journal of Family Psychology, 18, 72-81.

Freud, Sigmund. 2001. Tafsir Mimpi. Terjemahan. Yogyakarta: Penerbit Jendela.

Freud, Sigmund. 2002. Psikoanalisis. Terjemahan: Yogyakarta: Ikon Teralitera

Hall, Calvin S. \& Gardner Lindzey. 2000. Teori Kepribadian 1. Yogyakarta: Penerbit Kanisius.

Hube, M. Darwis. 2006.Penjelajahan Religio-Spiritual tentang Emosi Manusia di dalam Al Quran, Jakarta: Erlangga.

Luznizanuri, Kiki \& H Fuad Nashori. 2013. Terapi relaksasi otot progresif dan zikir efektif menurunkan kecemasan hipertensi esensial pralansia. Tesis. Yogyakarta: Program Pascasarjana Fakultas Psikologi dan Ilmu Sosial Budaya UII

Martin, Anthony Dio. 2003. Emotional Quality Management: Refleksi, Revisi dan Revitalisasi Hidup Melalui Kekuatan Emosi. Jakarta: Penerbit Arga.

Mujib, Abdul \& Jusuf Mudzakir. 2001. Nuansa-nuansa Psikologi Islam.Jakarta: Rajagrafindo persada.

Najati, M Utsman. 2001. Al Qur'an dan Ilmu Jiwa. Bandung: Penerbit Aras Pustaka.

Najati, M Utsman. 2005. Hadits dan Ilmu Jiwa. Terjemahan. Bandung: Penerbit Pustaka.

Nashori, H. Fuad. 2008. Potensi-potensi Manusia. Yogyakarta: Penerbit Pustaka Pelajar.

Nashori, H. Fuad. 2010. Agenda Psikologi Islami. Yogyakarta: Penerbit Pustaka Pelajar.

Nashori, H Fuad \& Kusdwiratri Setiono, K. 2010. Pemaafan pada Etnis Jawa: Sebuah Kajian Teoritik. Jurnal Psikoislamika, 7 (1), 105-116.

Sadif, Ria Safaria. 2013. Terapi relaksasi zikir efektif menurunkan stres penderita ginjal kronik yang menjalani hemodialisis. Tesis. Yogyakarta: Program Pascasarjana Fakultas Psikologi dan Ilmu Sosial Budaya UII

Sutoyo, Anwar. 2007. Bimbingan dan Konseling Islami. Semarang: Cipta Prima Nusantara.

Tim Tarjamah. 2006. Al Qur'anul Karim dan Tarjamahannya. Kementrian Agama Republik Indonesia

Wahyunita, Dina. 2013. Pelatihan relaksasi zikir efektif meningkatkan kesejahteraan subjektif istri yang mengalami infertilitas. Tesis. Yogyakarta: Program Pascasarjana Fakultas Psikologi dan Ilmu Sosial Budaya UII.

Wallace, Harry M., Julie J. Exline, \& Roy F. Baumeister.2008. Interpersonal Consequences of Forgiveness: Does Forgiveness Deter or Encourage Repeat Offenses? Journal of Experimental Social Psychology, 44 (2), 453-460.

Worthington Jr, Everett L., W.C. van Oyen, A.J. Lerner, \& M. Scherer. 2005. Forgiveness in Health Research and Medical Practice. Explore, 1(3), 169-176. 